\title{
Thermoplastic high performance composite gears
}

\section{3rd International Conference on High Performance Plastic Gears 2019}

\author{
Dr. Hans-Jörg Dennig, Severino Monn: Both Zurich University of Applied \\ Sciences, Winterthur Switzerland; Dr. Albert Vodermayer, icotec AG, Alt- \\ stätten, Switzerland
}

\section{Abstract}

This paper describes the development and testing of gears based on polyetheretherketone (PEEK) and endless carbon fibers. Behind these results is a research project funded by INNOSUISSE with the aim of developing plastic gears with which much higher strengths than previously available gears can be achieved. In principle, two types of gearwheels are investigated which differ in their manufacturing method: icotec's injection molding CFM (Composite flow moulding) process and milled gears (GP) made of composite plate materials.

The wheels produced in the CFM process have very good static strength. However, the expected performance in the running tests could not be achieved due to insufficient dimensional accuracy from the CFM process. Comparative tests with GP gears were able to confirm the expected service life.

For example, the tests with a line load of $60 \mathrm{~N} / \mathrm{mm}$ were terminated after approximately $10^{6}$ load cycles, since the wear was limited to the run-in amount and no failure was to be expected. During dry running tests in a range of $10^{5}-10^{6}$ cycles a load $>129 \mathrm{~N} / \mathrm{mm}$ was run.

\section{Introduction}

Currently, the gear market is dominated by metal gears and plastic gears. The main advantages of plastic gears compared to steel gears are the lower manufacturing costs, the weight and the possibility of dry-running operation. The main disadvantages are the low load capacity and the limited temperature range. To increase the load-bearing capacity, reinforcing fibres such as glass and carbon fibres can be used in combination with a high-performance polymer. To this end, the Centre for Product and Process Development (ZPP) of the Zurich University of Applied Sciences (ZHAW) is investigating gears made of polyetheretherketone (PEEK) and endless carbon fibres. This paper explains the objectives of the project as well as the advantages and disadvantages of these gears.

\section{State of the Art}

For the current state of the art in the field of plastic gearing, the following topics will be discussed: failure modes of plastic gears, materials, lubrication and manufacturing. Currently, the damage to plastic gears shown in Table 1 can be detected. 
Table 1: Potential modes of failure and their causes for plastic gears according to

\begin{tabular}{|c|c|}
\hline Failure mode & Cause \\
\hline Melting & $\begin{array}{l}\text { The melting temperature of the material at the teeth is exceeded; } \\
\text { more heat is added than dissipated. The tooth temperature rises } \\
\text { steadily. Due to the temperature increase in the plastic tooth, the } \\
\text { mechanical strength decreases continuously until it is too low for } \\
\text { force transmission. The teeth soften or are pushed away within a } \\
\text { very short time. }\end{array}$ \\
\hline $\begin{array}{l}\text { Tooth root frac- } \\
\text { ture }\end{array}$ & $\begin{array}{l}\text { Too high bending stress at the tooth root: If the bending strength of } \\
\text { the plastic tooth is too low, bending fracture occurs outside the wear } \\
\text { channel, where the flank does not come into contact with the oppo- } \\
\text { site flank. }\end{array}$ \\
\hline Pitting & $\begin{array}{l}\text { Hertzian pressure is too high with superimposed shear stress; pitting } \\
\text { is the result of fatigue of the material in the near-surface area. The } \\
\text { pitting is also effected by the shear stresses and the thermal } \\
\text { stresses due to the sliding of the flanks }\end{array}$ \\
\hline High wear & $\begin{array}{l}\text { Low wear resistance or strong abrasive surface of the friction part- } \\
\text { ner; caused in part by chipping and in part by abrasion. This is espe- } \\
\text { cially the case on the tooth root and head, where the highest sliding } \\
\text { speed occurs. Wear, when mating the same plastics with each } \\
\text { other, is particularly high, especially on gears reinforced with short fi- } \\
\text { bres. }\end{array}$ \\
\hline $\begin{array}{l}\text { Tooth fracture on } \\
\text { the flank }\end{array}$ & $\begin{array}{l}\text { Crack formation due to Hertzian pressure and shear stresses at the } \\
\text { wear zone, the crack grows into a fracture due to the bending stress. }\end{array}$ \\
\hline Deformation & $\begin{array}{l}\text { Occurs in both static and dynamic cases: } \\
\text { Static: Deformation is caused by flow of the material. The long-term } \\
\text { modulus of elasticity is exceeded when a static load is applied. } \\
\text { Dynamic: The short-term modulus of elasticity is exceeded. In both } \\
\text { cases, the tooth head play is reduced and can lead to clamping of } \\
\text { the gear stage. }\end{array}$ \\
\hline
\end{tabular}

In principle, with PEEK, both with and without fibre reinforcement in the lubricated state, a number of cycles of around $\geq 10^{7}$ at a line load $\geq 50 \mathrm{~N} / \mathrm{mm}$ can be expected before damage occurs .

PA and POM are currently the most widely used plastics for gear wheels, accounting for more than $85 \%$. They have proven to be superior to other gear plastics (e.g. polycarbonate, polyethylene), especially for power transmissions. At higher ambient temperatures, the load carrying capacity of PEEK gears is superior to POM. It also has good friction and wear properties. The disadvantage of this plastic is that it is costly.

Figure 1 clearly shows that in the case of fibre-reinforced gears, the fibres of the injectionmoulded gears lie straight in the edge area of the tooth root, where the tensile stress is maximum, in the tensile direction. The milled gears do not have such a fibre orientation that is suitable for the stress, as they were milled from extruded rods. The fibres lie in the axial direction and therefore do not increase the strength. The different types of production allow different tooth root strengths to be expected with the same material. 

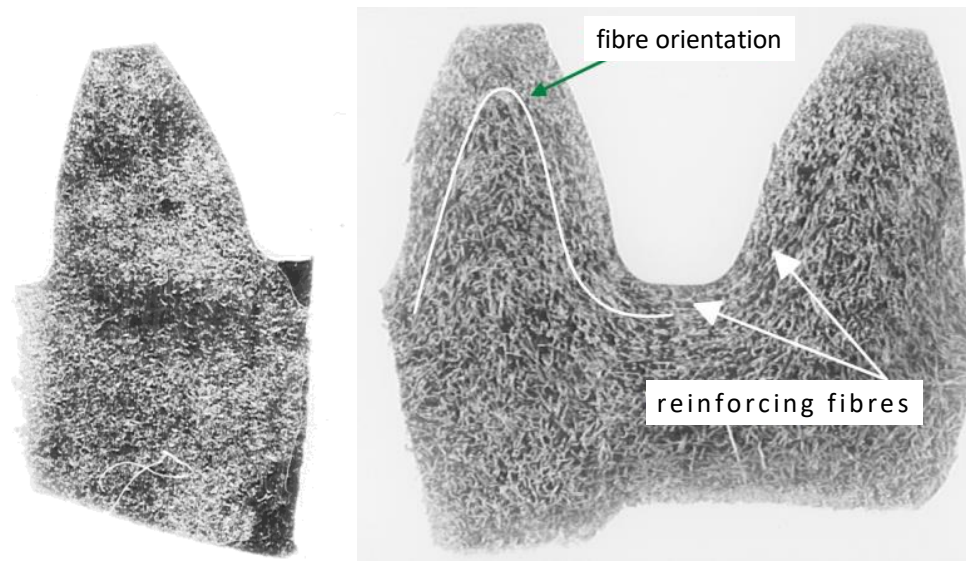

Figure 1: Fiber orientation for gears milled from extruded material (left) and injection molded (right)

All previous investigations confirm that the plastic/steel pairing is better suitable for higher performance compared to the plastic/plastic spur gear pairing. It provides better heat dissipation for both dry running and grease/oil lubrication running, due to the better heat dissipation of the steel gear.

Heym detected more pitting in grease-lubricated steel/PEEK gearboxes compared to steel/POM gearboxes. The reason for this is that the higher modulus of elasticity of PEEK, causes a higher flank pressure with the same line load. Despite lower strength values, POM wheels can achieve a longer service life than PEEK wheels. A similar effect is observed with fiber additives. Although the fibers used to increase strength prevent creep in the component, they also increase wear.

A single application of grease lubrication increases the life time value. A significant increase in the load-bearing capacity compared to dry-running operation can be recorded. However, the peripheral speeds are limited. An increase of the load capacity can be achieved by oil lubrication. In addition to the actual lubrication effect, there is also the positive effect of improved heat dissipation by the oil.

\section{Manufacturing:}

Short fibre reinforced plastic gears are mainly produced by injection moulding. In order to avoid the influence of weld lines on the injection-moulded gears, they can be manufactured with a shield gate (Figure 2).
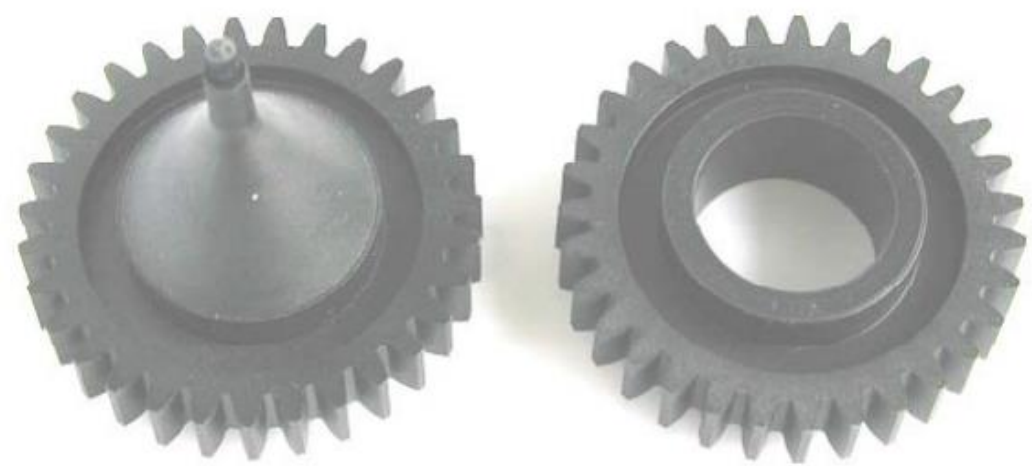

Figure 2: Injection molded gear blank (left) and finished test gear (right) 
A disadvantage of this production is the necessary subsequent machining. The shield gate must be lathed off and the bore must be lathed to size. The fiber orientation of the injectionmolded gears is much more appropriate for the stress than that of the milled gears (Figure 1).

Gears made of continuous fibre composites are currently manufactured mechanically, exclusively from semi-finished panel products.

Another possibility is offered by the CFM process, which can be used to produce complex components with a high content of endless carbon fibres reinforced thermoplastics. "Endless" means that the carbon fibres pass through the component without interruption from one end to the other (Figure 3). This type of composite material is processed by a special impact extrusion process and has so far mainly been used in the medical sector. The raw material is a so-called fibre composite material, which is composed of high-tech plastics. This composite material is processed into the finished product using an injection moulding process. The starting material is injected in a molten state into the preheated cavity of the mould and then cooled. The three-dimensionally interlaced fibres in the component create extraordinary stability. Small and complex shapes are possible. Until now, no gear wheels have been produced using this process.

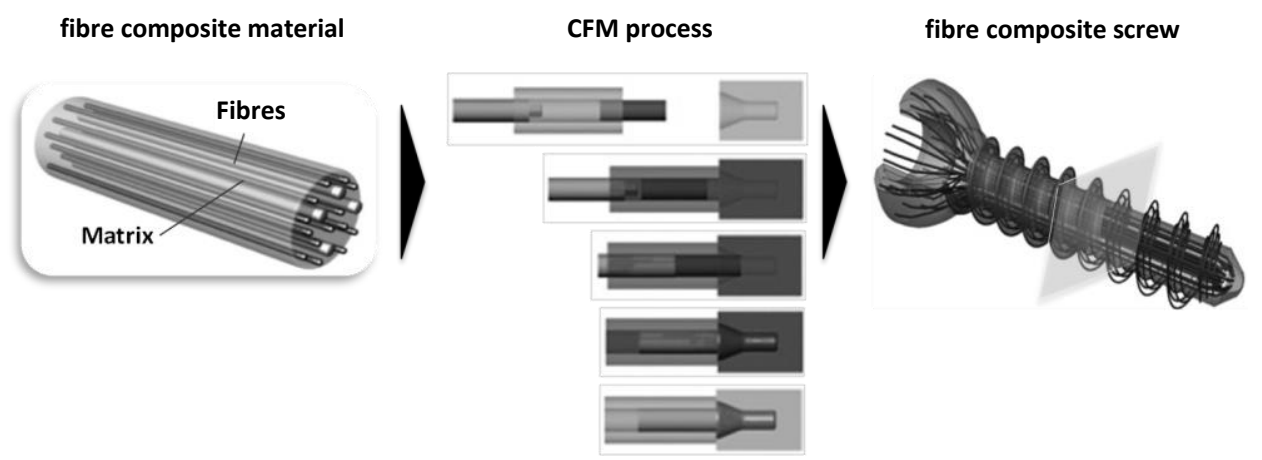

Figure 3: CFM process using the example of a screw

Important design information for thermoplastic gears is contained in VDI Guideline 2736 parts 1, 2, 4. They are all based on experimental gear testing. The guidelines show that the load capacity of the plastic gears can only be estimated.

Rössler has already investigated the gearing qualities of injection molded PEEK. The tooth qualities are determined with the two-flank rolling test and with the flank shape measurement. A toothing quality of $>12$ could be achieved with fibre-reinforced PEEK gears.

\section{Preliminary Testing}

To investigate the basic feasibility of the manufacturing and strength of a CFM wheel, preliminary tests were carried out with a small gear $\varnothing 25 \mathrm{~mm}, \mathrm{~m}=0.5 / 1 \mathrm{~mm}, \mathrm{~b}=7.5 \mathrm{~mm}$. A modular tool was developed for the production with which different sprue variants are possible. This makes it possible to achieve an optimum fibre orientation structured on the tooth flank (Figure 4). 

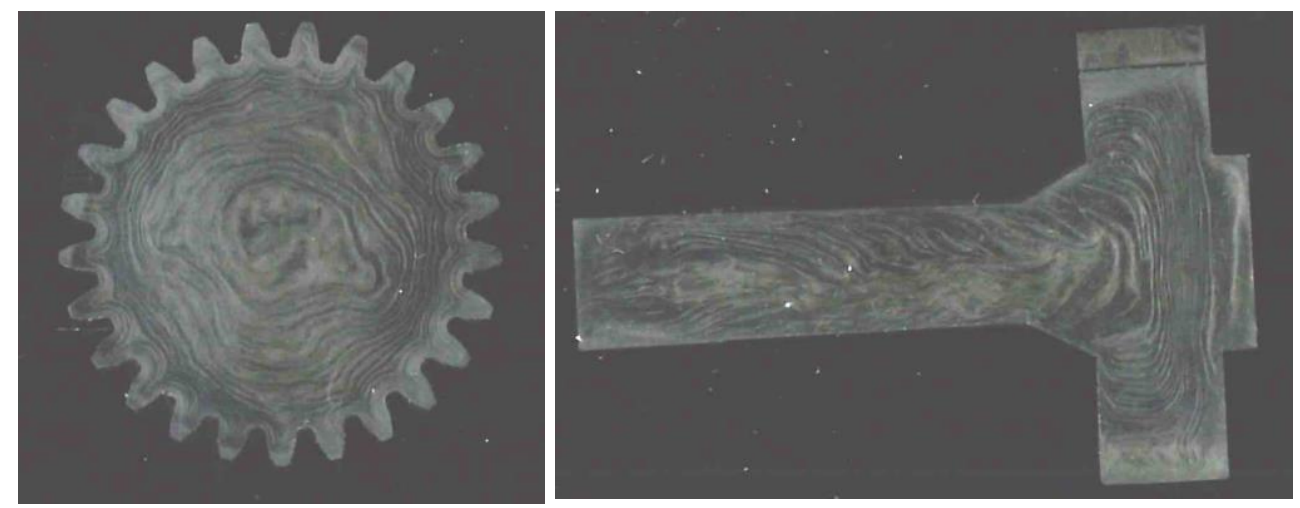

Figure 4: Cross and longitudinal grinding of a CFM gear wheel

The blanks were machined and manufactured with a feather key for a 2-shaft system and with a bush for a 3-shaft system (Figure 5, Figure 6). As a comparison, milled panels with the same material composition were used. The fibre layers are arranged quasi-isotropically in four packages of $0^{\circ}, 45^{\circ}, 90^{\circ}$ and $-45^{\circ}$. The gears produced are conditioned. This means that the water absorption is complete, and the material characteristics are fixed (Table 2).

Table 2: Material Parameters 45\% PEEK + 55\% CF

\begin{tabular}{|l|c|c|c|}
\hline Temperature & $23^{\circ} \mathrm{C}$ & $80^{\circ} \mathrm{C}$ & $100^{\circ} \mathrm{C}$ \\
\hline Coefficient of friction Oil & $0.10-0.20$ & $0.10-0.20$ & $0.10-0.20$ \\
\hline Coefficient of friction dry & $0.25-0.3$ & $0.25-0.3$ & $0.25-0.3$ \\
\hline E-Modul / MPa & 40000 & 38000 & 35000 \\
\hline Wear Coefficient dry & 0.2 & - & - \\
\hline Tensile threshold strength / MPa & $100-200$ & $90-180$ & $80-160$ \\
\hline Ultimate tensile strength / MPa & 400 & 360 & 320 \\
\hline Yield strength / MPa & $250-300$ & 225 & 200 \\
\hline
\end{tabular}

To increase the concentricity accuracy, the CFM wheels were partly turned out centrically. After manufacturing, the base tangent length, the roundness and the tooth to tooth error fi" were measured (Table 3).

The test setup is a non-mechanically closed loop test rig (Figure 7). The centre distance of the main shafts is $60 \mathrm{~mm}$. For the pre-test, the temperature wasn't controlled exactly.

Table 3: Measurement results of the first batch of gears

\begin{tabular}{|c|c|c|c|c|c|c|c|}
\hline all values in $\mathrm{mm}$ & $\begin{array}{l}\text { Quality } \\
\text { SET }\end{array}$ & $\begin{array}{c}\text { Fr" } \\
\text { ACTUAL }\end{array}$ & $\begin{array}{l}\text { Fr" } \\
\text { SET }\end{array}$ & $\begin{array}{c}\text { fi" } \\
\text { ACTUAL }\end{array}$ & $\begin{array}{c}\text { fi" } \\
\text { SET }\end{array}$ & $\begin{array}{c}\mathrm{W}_{\mathrm{k} 1} \\
\text { ACTUAL }\end{array}$ & $\begin{array}{c}\mathrm{W}_{\mathrm{k} 1 \max , \min } \\
\text { SET }\end{array}$ \\
\hline CFM, $\mathrm{m}_{\mathrm{n}}=1 \mathrm{~mm}$ & $10 \mathrm{e}$ & 0.084 & \multirow{2}{*}{0.052} & 0.029 & \multirow{2}{*}{0.037} & 7.630 & \multirow{2}{*}{$7.66-7.613$} \\
\hline CFM, $m_{n}=1 \mathrm{~mm}$, centrically turned & $10 e$ & 0.066 & & 0.032 & & 7.622 & \\
\hline $\mathrm{GP}, \mathrm{m}_{\mathrm{n}}=1 \mathrm{~mm}$ & $8 f$ & 0.020 & 0.027 & 0.010 & 0.017 & 7.686 & $7.683-7.707$ \\
\hline $\mathrm{GP}, \mathrm{m}_{\mathrm{n}}=0.5 \mathrm{~mm}$ & $8 f$ & 0.029 & 0.027 & 0.009 & 0.017 & 8.430 & $8.447-8.427$ \\
\hline
\end{tabular}



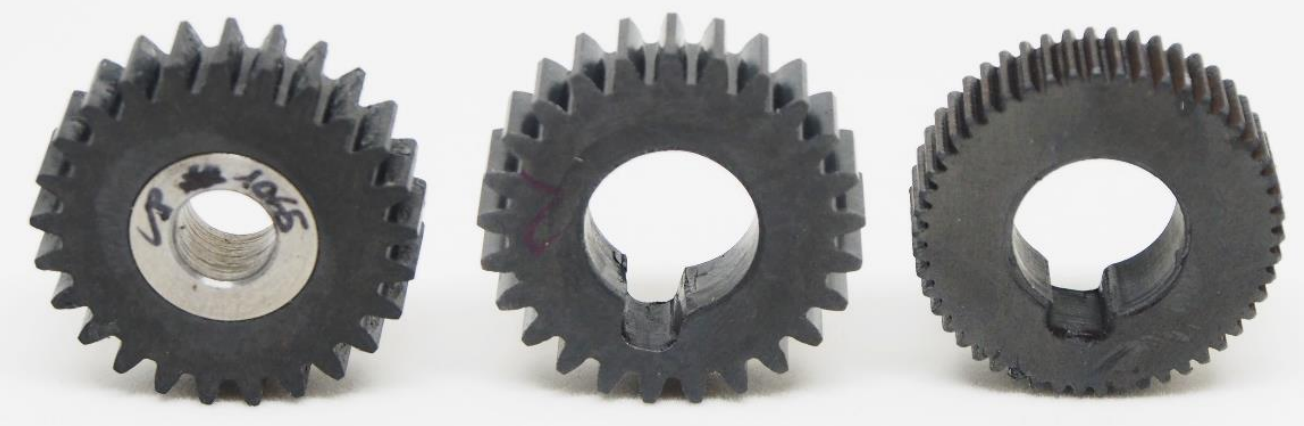

Figure 5: Various CFM Gears $\varnothing 25 \mathrm{~mm}$
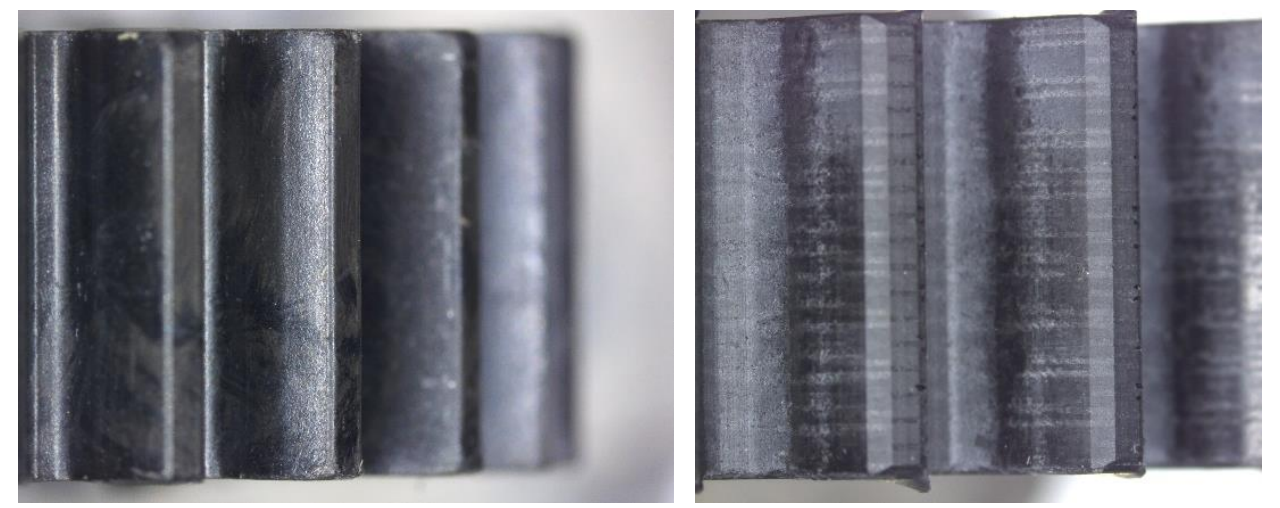

Figure 6: Surface of raw CFM (left) and raw flank of GP Gears $\varnothing 25 \mathrm{~mm}$

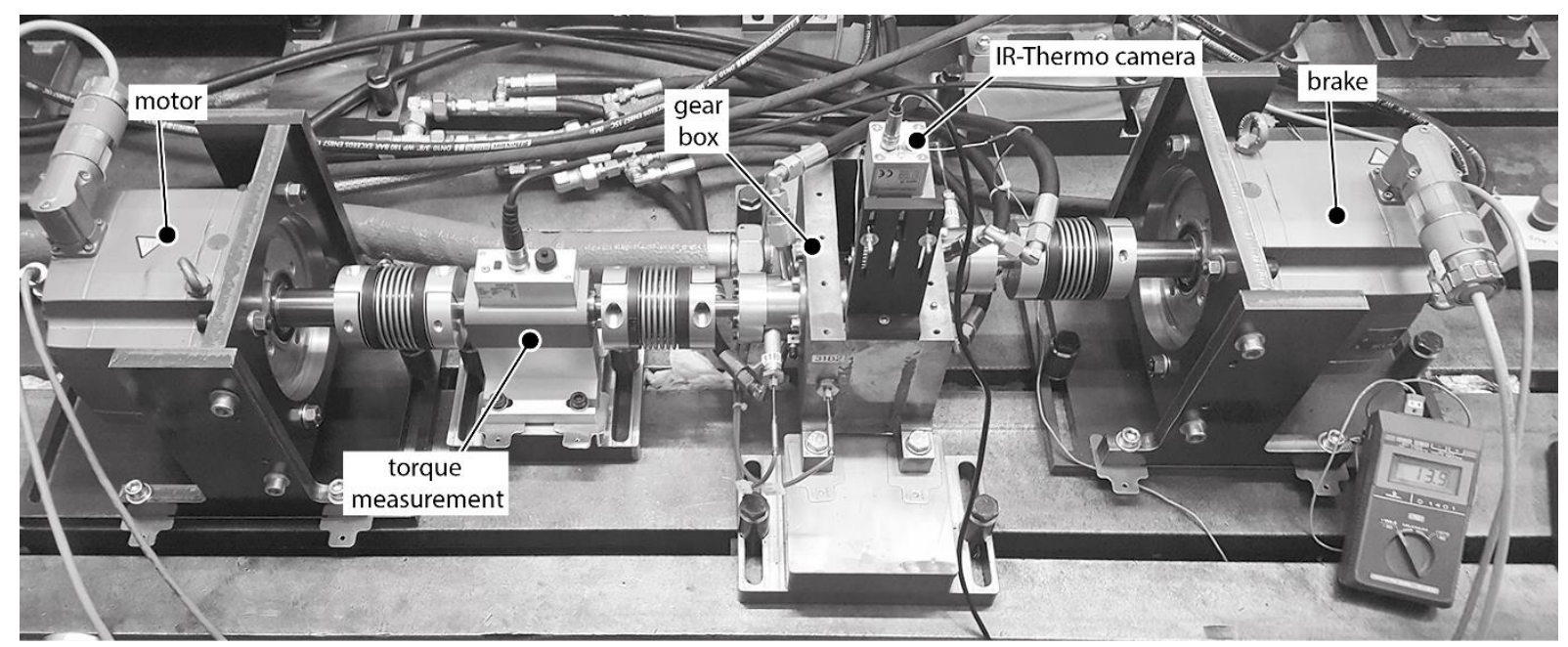

Figure 7: ZPP test rig

The result is shown in Figure 8 - Figure 11, where the following key statements can be made with respect to the load cycles:

- The CFM-manufactured gears have a significantly poorer concentricity without centric machining, resulting in very low load cycles, both dry and lubricated.

- The load cycles can be increased by centric finishing of the CFM wheels.

- CFM wheels show poorer concentricity values after centric finishing compared to the milled plate (GP) wheels, which tends to lead to poorer load cycle numbers.

- The gears manufactured with a module of $0.5 \mathrm{~mm}$ achieve, as expected, only minimally fewer load cycles compared to $\mathrm{m}=1 \mathrm{~mm}$.

- The mechanically produced gears made of plate material in the lubricated state at 
$30 \mathrm{~N} / \mathrm{mm}$ exceed the values in the literature .

- All tests with $30 \mathrm{~N} / \mathrm{mm}$ were stopped at approximately $10^{6}$ load cycles. There are no comparative values in the literature for high loads in the dry state.

- CFM Gears fail due to tooth root fracture.

- GP Gears fail due to delamination of the sheet material.

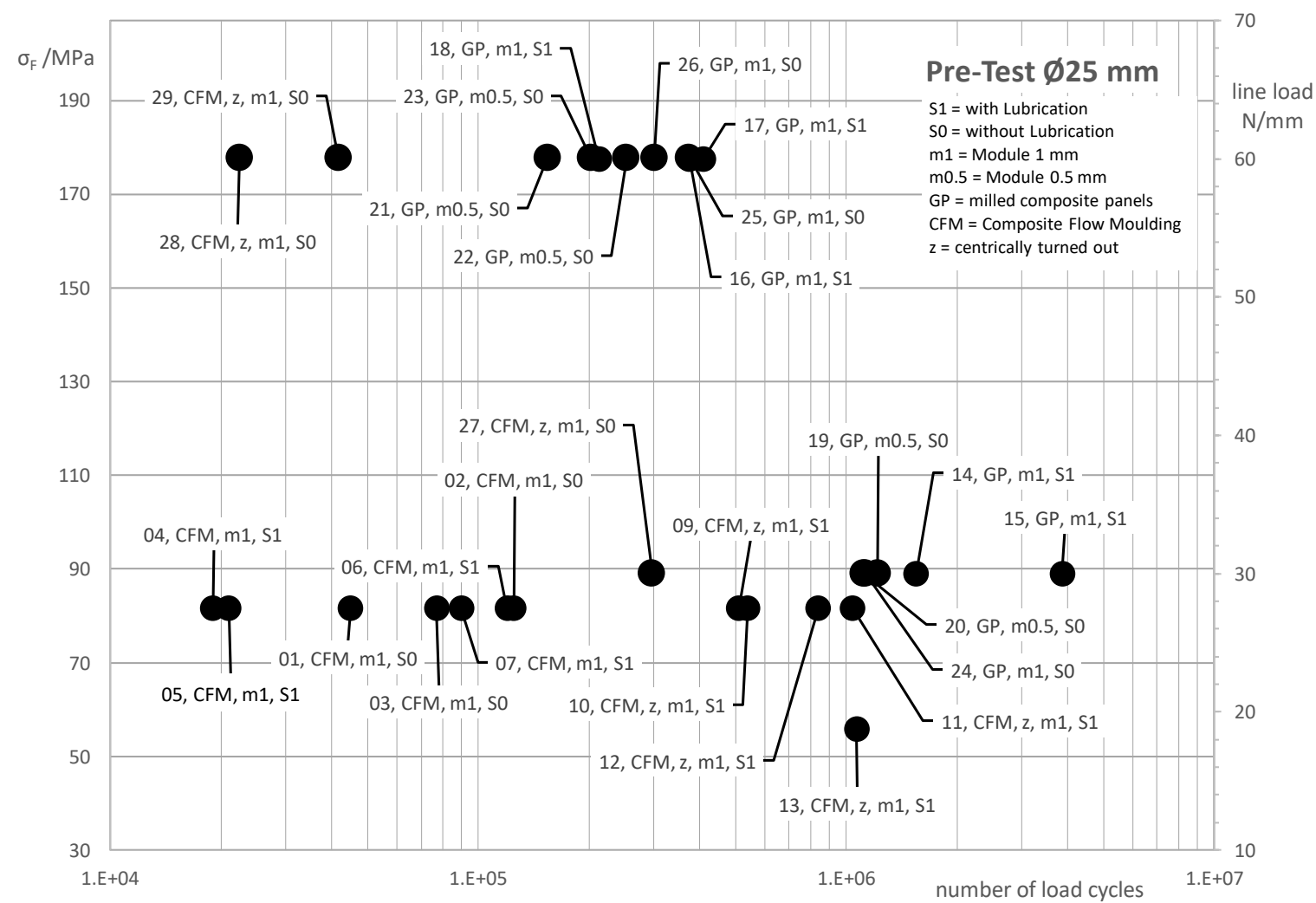

Figure 8: Result of the pre-tests
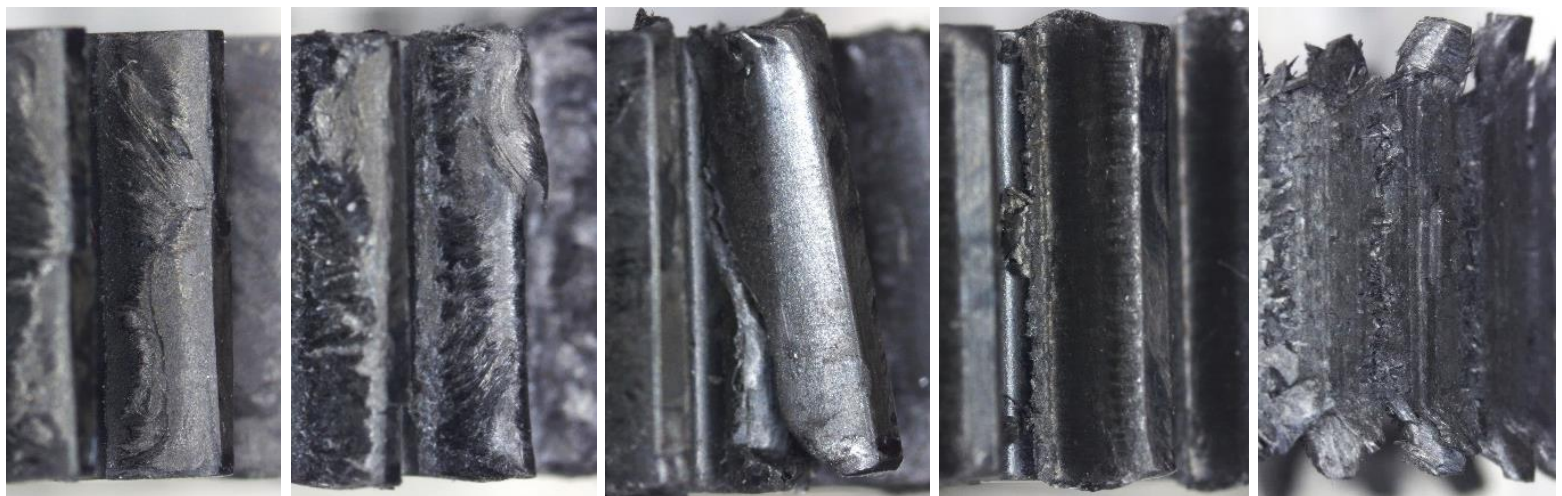

Figure 9: Various stages of failure progression on CFM Gears (from left to right)
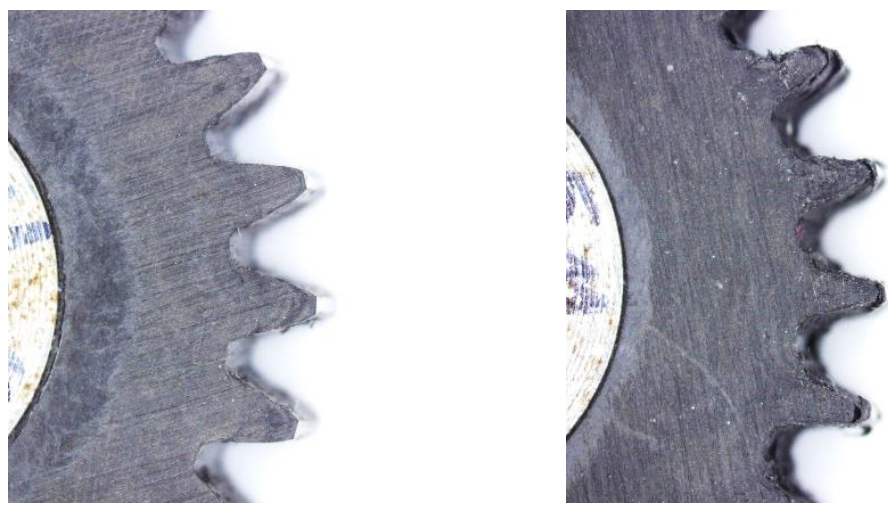

Figure 10: CFM Gear (12) after 8.44E5 cycles (left), CFM Gear (10) after 5.11E5 

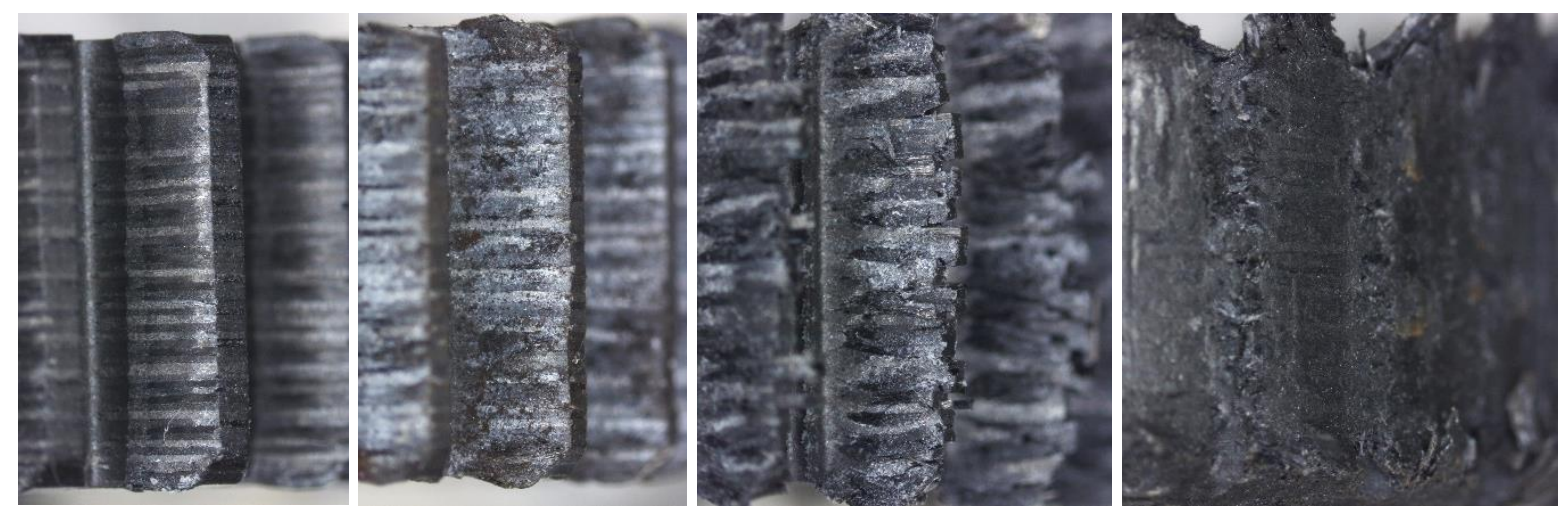

Figure 11: Various stages of failure progression on GP Gears (from left to right)

\section{Strength verification size 2 VDI 2736}

Based on the preliminary tests, it was decided to focus on the milled plate wheels and to carry out further tests according to VDI 2736 based on size 2 with the gears specified in Table 4. All test results were evaluated according to the specifications of VDI 2736 Part 4. The manufactured gears meet all the tooth widths specified in Table 4. With a few exceptions, the toothing quality corresponds to a quality of $10 \mathrm{e}$ according to DIN 58405.

Table 4: Gear properties and steel gear dimensions (right)

\begin{tabular}{|l|l|}
\hline Symbol & Value \\
\hline Centre Distance $\mathrm{a}$ & $60 \mathrm{~mm}$ \\
\hline Normal module $\mathrm{m}_{\mathrm{n}}$ & $2 \mathrm{~mm}$ \\
\hline Tooth number $\mathrm{z}_{1} ; \mathrm{z}_{2}$ & 31,29 \\
\hline Face width $\mathrm{b}_{1} ; \mathrm{b}_{2}$ & $8 \mathrm{~mm} ; 13 \mathrm{~mm}$ \\
\hline Tip diameter $\mathrm{d}_{\mathrm{a} 1 \mathrm{max}} ; \mathrm{d}_{\mathrm{a} 1 \mathrm{~min}}$ & $66 \mathrm{~mm} ; 65.97 \mathrm{~mm}$ \\
\hline Tip diameter $\mathrm{d}_{\mathrm{a} 2 \mathrm{max}} ; \mathrm{d}_{\mathrm{a} 2 \mathrm{~min}}$ & $62 \mathrm{~mm} ; 61.97 \mathrm{~mm}$ \\
\hline Root diameter $\mathrm{d}_{\mathrm{f} 1 \mathrm{max}} ; \mathrm{d}_{\mathrm{f} 1 \mathrm{~min}}$ & $56.85 \mathrm{~mm} ; 56.75 \mathrm{~mm}$ \\
\hline Root diameter $\mathrm{d}_{\mathrm{f} 2 \mathrm{max}} ; \mathrm{d}_{\mathrm{f} 2 \mathrm{~min}}$ & $52.9 \mathrm{~mm} ; 52.83 \mathrm{~mm}$ \\
\hline Tip rounding radius, gear 2 & $0.6 \mathrm{~mm}$ \\
\hline Pressure angle $\alpha_{\mathrm{n}}$ & $20^{\circ}$ \\
\hline Helix angle $\beta$ & $0^{\circ}$ \\
\hline Addendum modification $\mathrm{x}_{1}, \mathrm{x}_{2}$ & $0 \mathrm{~mm}$ \\
\hline Tooth Quality & $10 \mathrm{e}(\mathrm{DIN} 58405) ; 7$ (DIN 3961) \\
\hline $\mathrm{h}^{*}{ }_{\mathrm{aP}}$ & 1 \\
\hline $\mathrm{h}_{\mathrm{fP}}$ & 1.25 \\
\hline$\rho^{*}{ }_{\mathrm{fP}}$ & 0.38 \\
\hline
\end{tabular}

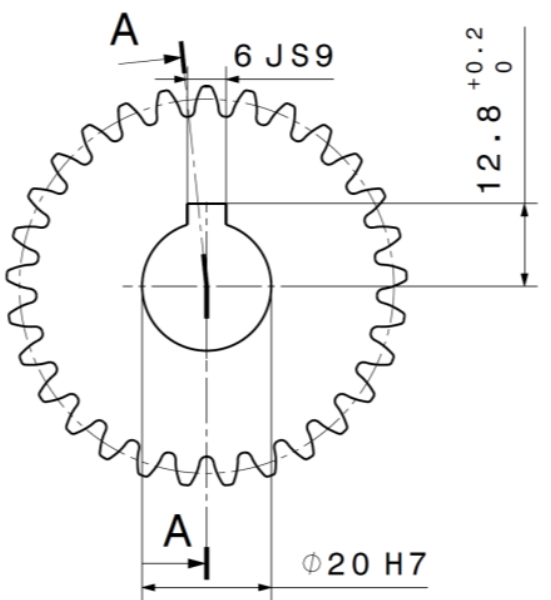

The investigations are executed in the combination between gear 1 (plastic) and gear 2 (steel) and with a centre distance of $60 \mathrm{~mm}$ in the ZPP test-rig (Figure 7). Gear 1 is the driving gear. All tests were driven at dry condition. The temperature of the flanks is steadily measured. To calculate the material properties, the temperature at the end of the investigation is evaluated. The tooth flank / surface temperature $T_{S}$ and the body temperature $T_{B}$ during operation are measured with a thermal camera. $T_{B}$ can be regarded as equivalent to the temperature of the tooth root.

For the tribological testing $\approx 0.75 \cdot 10^{6}$ load cycles are aimed at a speed of $n=1500 \mathrm{rpm}$, $\mathrm{T}_{\mathrm{B}} \approx 75^{\circ} \mathrm{C}$, root stress $\sigma_{\mathrm{F}}=168 \mathrm{MPa}$. According to DIN 3960, the tooth width $\mathrm{W}_{\mathrm{k}}$ is measured and the wear coefficient $k_{w}$ (formula 1 ) can be calculated. The limit for $W_{\text {lokal }}$ is defined as $20 \%$ of the modul $m_{n}$. 


$$
k_{w}=\frac{W_{\text {lokal }}}{N_{L}} \cdot \frac{b}{F_{n, l o k a l}} \cdot \frac{1}{\zeta}
$$

The Fatigue tests were driven at two body temperatures: $\mathrm{T}_{\mathrm{B}} \approx 75^{\circ} \mathrm{C}, 100{ }^{\circ} \mathrm{C}$. The drive speed is always $1500 \mathrm{~min}^{-1}$. Figure 12 shows examples of the damage.
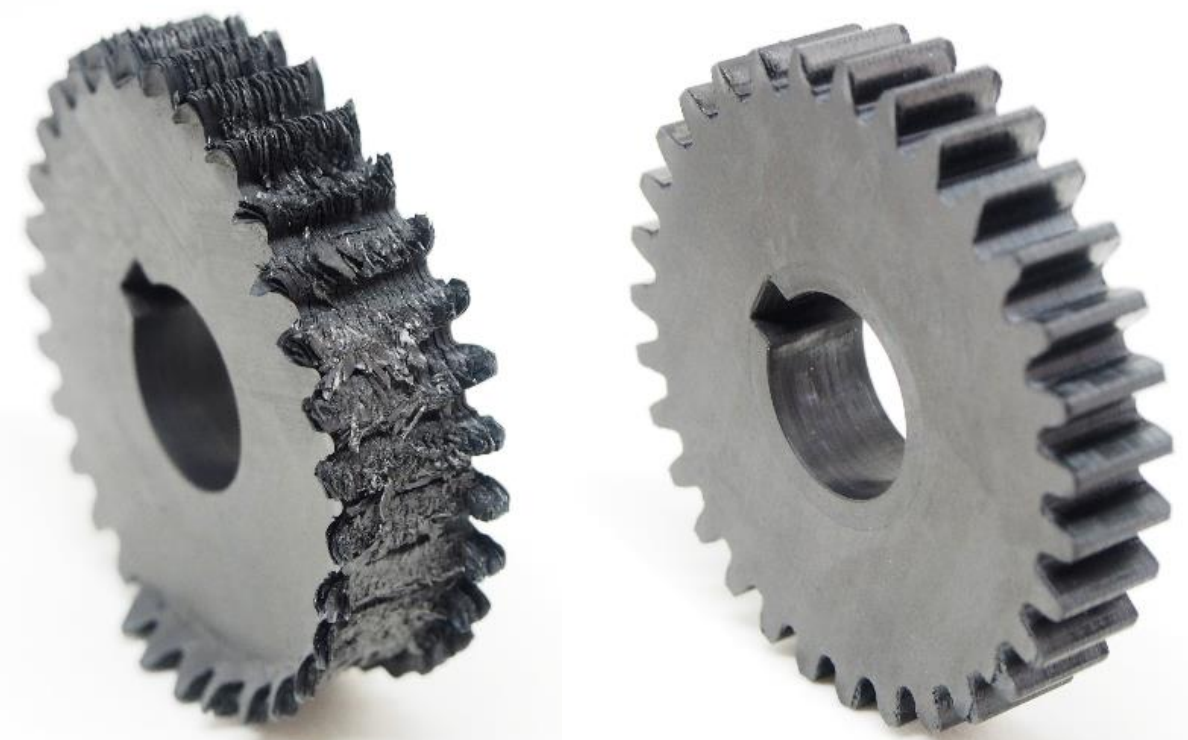

Figure 12: Damage of the PG Gear (left), raw Gear (right)

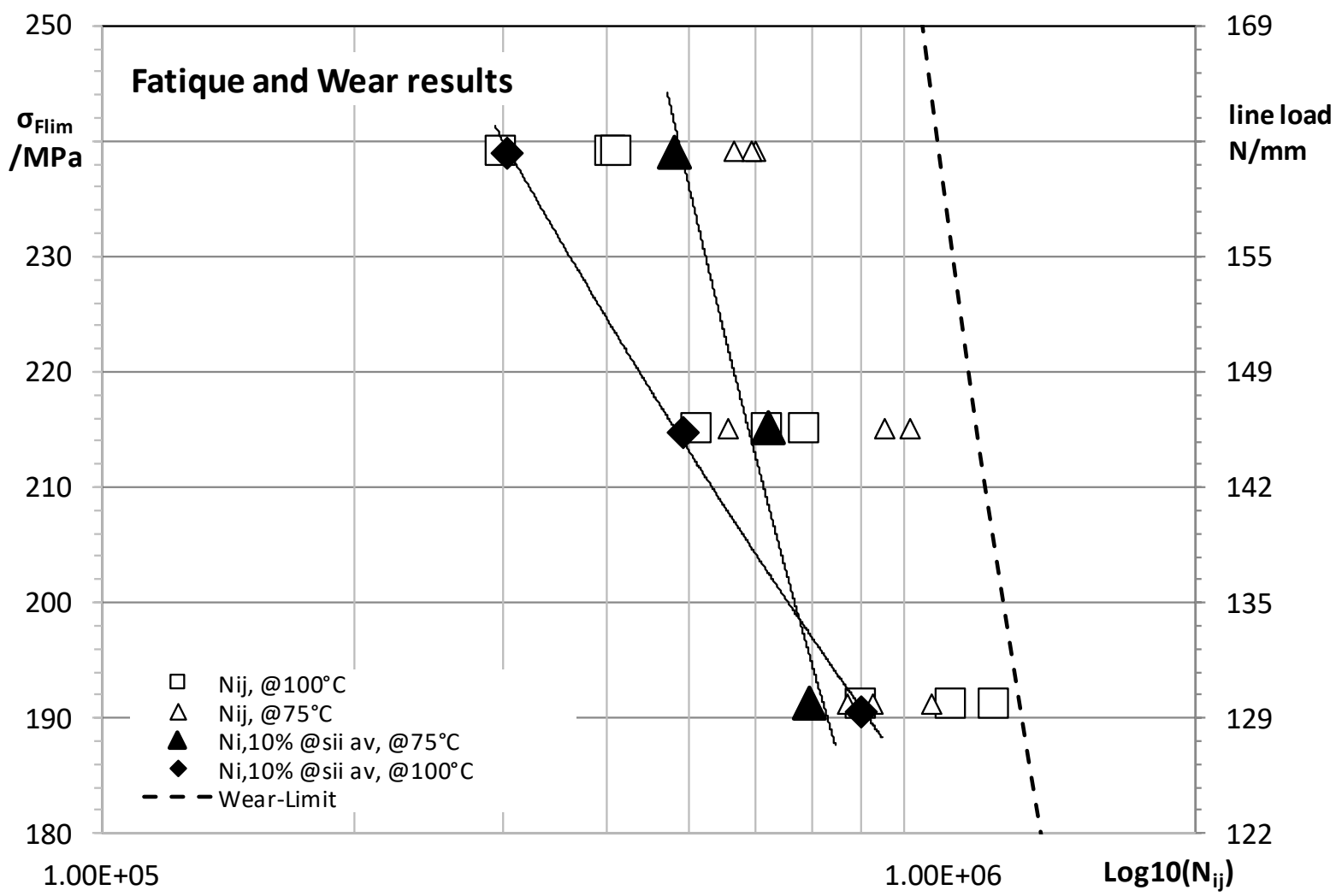

Figure 13: Comparison of the first with the second condition

Figure 12 shows the failure mode of the gears. Similar to Figure 11, delamination occurs. Figure 13 shows that the characteristic strength curves intersect at $75^{\circ} \mathrm{C}$ and $100{ }^{\circ} \mathrm{C}$. The strength curves are shown in the following figure. There are several reasons for this behavior: The damping of the material at high temperatures is better and therefore higher loads 
can be tolerated. To be able to conclusively assess this behaviour, however, further investigations must be carried out. It is evident that the bearable tooth root stresses are much higher than originally assumed. For example, $129 \mathrm{~N} / \mathrm{mm}$ are already achieved with a root stress of $190 \mathrm{MPa}$.

\section{Conclusion}

Compared to other plastic gear materials available on the market, the gears produced from the plate material are very well suited for applications with very high moments, high temperatures and rather slow movements. A possible field of application are for actuators that are located in the vicinity of heat sources and do not require lubrication. The material performs less well for high sliding speeds and low loads. In this range it is inferior to a POM. In addition, the preliminary tests have shown that a CFM wheel is precisely manufactured by tool adjustments and thus achieves load cycles similar to those of a GP wheel. For example, this can be used in hybrid structures. The core could be produced using the CFM process and then coated with a fibreless material.

A material data set was developed from the tests, which is available for KISSsoft.

\section{References in this document}

[1] VDI-Richtlinie, VDI 2736:2014-06 Blatt 1: Thermoplastische Zahnräder - Werkstoffe, Werkstoffauswahl, Herstellverfahren, Herstellgenauigkeit, Gestalten, Berlin: Beuth Verlag, 2014.

[2] J. Rössler, Zur Tragfähigkeitsberechnung thermoplastischer Zahnräder mit Füllstoffen, Berlin: TU Berlin, 2005.

[3] H. Linke und J. Börner, Stirnradverzahnung: Berechnung, Werkstoffe, Fertigung, München: Hanser, 1996.

[4] N. Tsukamoto, "Argument on Plastic Gears for Power Transmission," JSME International Journal, vol. C, no. 38, pp. 1-7, 1995.

[5] J. Rösler und T. O., "Experimental Studis of Plastic Gears without Lubrication,» in Proceedings of DETC'00; 8th International ASME Power Transmission and Gearing Conferece, Baltimore, Maryland, 2000.

[6] B. Heym, Tragfähigkeitsoptimierung trockenlaufender Kunststoff-Stahl-Zahnradpaarungen durch Einsatz von Verbundwerkstoffen und geometrischer Zahnkorrektur, Technische Universität Berlin, 1997.

[7] G. Klein, Untersuchungen zur Tragfähigkeit und zum Verschleißverhalten von geradverzahnten Stirnrädern aus thermoplastischen Kunststoffen bei einer Radpaarung Stahl-Kunststoff, TU Berlin, 1967.

[8] W. Beitz und E. Siedke, «Einsatz von Kunststoffzahnrädern im Maschinenbau,» VDI-Berichte Nr. 195, 1973.

[9] VDI-Richtlinie, VDI 2736:2013-01 Blatt 2: Thermoplastische Zahnräder - Stirnradgetriebe Tragfähigkeitsbrerechnung, Berlin: Beuth Verlag, 2013.

[10] VDI-Richtlinie, VDI 2736:2013-01 Blatt 4: Thermoplastische Zahnräder - Ermittlung von Tragfähigkeitskennwerten an Zahnrädern, Berlin: Beuth Verlag, 2016.

[11] DIN 3963: 1978-08, Toleranzen für Stirnradverzahnungen; Toleranzen für Wälzabweichungen.

[12] DIN 3962-2: 1978-08, Toleranzen für Stirnradverzahnungen; Toleranzen für Flankenlinienabweichungen. 